\title{
Terrestrial gastropods of Faure Island, Shark Bay, Western Australia
}

\author{
Barry Wilson \\ 4 St Ives Loop, Kallaroo, Western Australia 6025 Australia; E-mail: murex@starwon.com.au
}

\begin{abstract}
Five species of land snails are reported from Faure Island, two are species of Bothriembryon, a South West Botanical Province genus, two belong to Eremean Province genera, while the fifth belongs to a cosmopolitan genus. The distribution and habitats of the species are discussed. The species are survivors of the terrestrial fauna that inhabited the region during the arid phase of the last glacial period, prior to isolation by the last Late Pleistocene transgression.
\end{abstract}

Key words: land snails, distribution, habitats, fossil history

\section{INTRODUCTION}

During the biological survey of Faure Island in May 2000 (Wilson 2008), and during subsequent field trips to the island, five species of land snails were collected. Specimens of three of these were collected alive while two were collected as empty shells from sand samples in red dune blowouts. It is uncertain whether the latter species are extant on the island as no live specimens have yet been collected.

Two of the living species belong to the bulimid genus Bothriembryon, a group that has its centre of distribution in the South West Botanical Province. The other living species belongs to the camaenid genus Plectorhagada. The family Camaenidae is widespread in northern and central Australia including the arid Eremaean Botanical Province. One of the two species found as empty shells belongs to the cosmopolitan genus Pupoides while the other is a succiniid, another family with a cosmopolitan distribution and widespread throughout Australia. Thus, the terrestrial snails of Faure Island are further evidence that this island lies on the boundary of the South West and Eremaean Botanical Provinces (Keighery and Muir 2008).

All of these snails were described from the Shark Bay area many years ago, testimony to the interest in the natural history of the bay in the early years before and after European settlement. One of the Bothriembryon species was collected by François Péron during the Baudin expedition in 1801. All the other species were first discovered by unknown collectors during the middle part of the $19^{\text {th }}$ century.

Alexander (1916) summarised the early voyages by naturalists along the Western Australia coast, including Shark Bay, and a brief historical account of land snail collecting in the region during the $19^{\text {th }}$ century was given by Iredale (1939) who also listed and redescribed the species recorded here. Kendrick and Wilson (1975) reviewed the very confused taxonomy of the two living species of Bothriembryon that occur in the region and clarified their nomenclature and differences between them.

The specimens referred to in this study have been lodged in the collections of the Western Australian Museum.

\section{BULIMULIDAE}

Bothriembryon onslowi (Cox, 1864: 185; figured Cox, 1868, pl. 13, fig. 13. Not Bothriembryon costulatus (Lamarck) Iredale, 1939). Type locality: Dirk Hartog Island.

The shells of this snail are inflated and have about 5 whorls. The protoconch has 1.7 to 2.2 whorls. There is a fine sculpture of granose spiral cords above the periphery. The mean height of a living and freshly dead sample comprising 22 adult specimens was $19.9 \mathrm{~mm}$ (range $16.5-21.7 \mathrm{~mm}$ ) and the height to width ratio about 3 to 2 .

Specimens of a fossil sample of the same species from semi-consolidated red dune sand immediately above a late Pleistocene shell bed (see below and Wilson 2008) were conspicuously larger with a mean height of $2.29 \mathrm{~mm}$ (range 18.9-25.6) although the number of whorls and height to width ratio was the same.

In live specimens the teleoconch whorls are chestnut-brown, interrupted by irregular, off-white to yellow axial flames. In dead shells exposed to sunlight the chestnut-brown fades to grey. Subfossil shells buried in red dune sand take on the orangebrown colour of the sand.

This species is somewhat similar to $B$. bulla found in the Perth region and the more distant $B$. melo of the South Coast and represents the most northerly population of that southwestern species group. 
Geographic distribution

Bothriembryon onslowi lives in tree-heath and Acacia shrublands on the mainland south of Shark Bay, with records from Peron Peninsula, Edel Land (Carrarang and Tamala Stations), Nanga Station, western part of Hamelin Station and Coburn Station and Dirk Hartog Island. A record from Coburn west of the North West Coastal Highway $47 \mathrm{~km}$ south of the Shark Bay turnoff, appears to represent the most southerly location of the species. There are no records of the species east of the Highway.

Kendrick and Wilson (1975) recorded this species as a post-Pleistocene fossil at several locations on mainland Shark Bay.

\section{Distribution and habitats on Faure Island}

This is the most common and widespread land snail species on Faure Island. Dead shells are scattered around on the red soil among wanu (Acacia ramulosa) scrub throughout the island. Live specimens may be found aestivating in deep leaf litter under the shrubs. The species is also found under Spinifex longifolius in the white Holocene dunes along the southern side of the island where it cohabits with $B$. costulatus.

Fossilised shells are common in semiconsolidated, red sand dunes. At the boat landing at the south western corner of the island specimens may be seen in an eroded face of a dune immediately above a supra-tidal marine deposit of shells believed to represent the highest sea level stand of the last Pleistocene interglacial period. These dunes were deposited over the marine deposits as the sea regressed, possibly before the period of extreme aridity that accompanied the final glacial event of the late Pleistocene (Kendrick et al. 1991). The fossil shells from this deposit are significantly larger than their living counterparts. A reasonable interpretation of this circumstance is that this snail species has occupied the region since the late Pleistocene but became smaller as a result of more arid conditions at the end of that period.

Bothriembryon costulatus (Lamarck, 1822: 122) Type locality: New Holland, probably Bernier Island (Kendrick and Wilson 1975).

The shells of this snail are smaller than those of $B$. onslowi and more elongate. They also have 5 whorls (but in a height of 14-20 mm) and a height to width ratio of about 3 to 2 . The protoconch consists of 1.9 to 2.3 finely sculptured whorls. The teleoconch of live specimens is off-white with axial streaks or flames of beige or pale brown.

In his journal Péron (1807: 120) recorded that on June 291801 at Bernier Island "Two species of land snail, extremely numerous, but all dead, occupied great stretches of the interior of the island, one was a small species of Helix (probably Rhagada torulus Férrussac, 1819), the other belonged the genus Bulimus (= Bothriembryon)." It is believed that specimens collected at that time became the type material later used by Lamarck in naming this species (Kendrick and Wilson 1975). Bothriembryon costulatus is the most northerly of a series of southwest species, including $B$. brazieri and $B$. kingii.

\section{Geographic distribution}

Coastal mainland sites between Red Bluff to Point Cloates, Dirk Hartog, Dorre and Bernier Islands on the outer side of Shark Bay, Salutation and Baudin Islands in the western gulf of the bay, and Peron Peninsula. There are no records from the mainland coast along the eastern side of Shark Bay. This record represents an outlier population in the eastern gulf of the bay, relating to the Peron Peninsula population.

Late Pleistocene fossil specimens of $B$. costulatus are found in lithified soil profiles in Edel Land, Peron Peninsula and the offshore islands and as far north as Quobba (Kendrick and Wilson 1975). It is sometimes associated with an extinct species of Bothriembryon (Kendrick 1978) and may have inhabited the Shark Bay region for longer than $B$. onslowi.

\section{Distribution and habitats on Faure Island}

The species appears to be confined to Holocene fore dunes along the southern side of the island where aestivating specimens may be found in litter beneath clumps of Spinifex longifolius. Specimens were not found in similar habitats fringing the eastern and western sides of the island.

\section{CAMAENIDAE}

Plectorhagada plectilis (Benson, 1853: 29; figured Reeve, 1853, pl. 172, sp. 1162). Type locality: Shark's [sic] Bay.

A small globular snail with height and width about equal. There are 1.5 smooth protoconch whorls and about 3 teleoconch whorls which are sculptured with rough, obliquely inclined axial plicae that give the shell a crumpled appearance. The shell is off-white to flesh-coloured but many specimens have an obscure brown peripheral band. This species is the type of its genus which has six nominate species found in the arid lands and islands of the Carnarvon Botanical District between Shark Bay and Cape Range. Apparently this species was collected several times and named by several different authors. A summary of its taxonomy and synonyms may be found in Iredale (1939) and Solem (1997). 


\section{Geographic distribution}

This snail is endemic to the Shark Bay area. It is found on the mainland coast on the eastern side of Hamelin Pool and south of the Shark Bay gulfs as far west as Tamala Station. It is not yet recorded from the Peron Peninsula. This is the first record of the species from an island. Iredale (1939) spoke of Dirk Hartog, Dorre and Bernier Islands and Peron Peninsula but there are no Western Australian Museum records of the species from those localities and the specimens to which he referred may have been $P$. carcharias (Pfeiffer 1864) which is known to occur at those localities (Solem 1997).

\section{Distribution and habitats on Faure Island}

On Faure Island this species of Spinifex has a very restricted distribution in two localities: along a calcrete breakaway above the eastern shore and in a patch of spinifex at the south end of the island. Live specimens have been found (though rarely) aestivating under stones of the calcrete ridge but a search for them in the sand and litter under spinifex at the other location proved unsuccessful.

The presence of Amplirhagada plectilis and $B$. onslowi represents the meeting of elements of two very different biogeographic provinces, the Eremaean and the South West Botanical Provinces, respectively. However, it seems that the two species do not share habitat although they occur in proximity of each other. At the eastern site, the camaenid does not extend more than a few metres into the wanu scrub while the Bothriembryon does not extend into the calcrete rocks. At the southern site, shells of the Bothriembryon do not appear among the spinifex but are common on the ground and in the litter in the surrounding wanu scrub.

\section{PUPILLIDAE}

Pupoides lepidulus (Adams and Angas, 1864; figured Cox, 1868, pl. 69, fig. 14). Type locality: Shark Bay.

These are tiny, cylindrical, umbilicate snails, up to $8 \mathrm{~mm}$ high, the height usually nearly three times the width although the height to width ratio is very variable in the sample. The 5-6 teleoconch whorls are smooth, convex and deeply sutured. The oval aperture is rimmed by a reflected outer lip and there is a prominent tubercle on the parietal wall. The shell is off-white to fawn and pellucid.

Solem (1986) gives the geographic range as extending from Broome to the Abrolhos with several other island and coastal mainland records. The species is said to be characterised by small size (mean length $4.37 \mathrm{~mm}$ ) and slender form but the Faure Island samples indicate great variability in both characters. Solem (1986) also records $P$. beltianus (Tate 1894), originally named from
Central Australia, from the Shark Bay area. It is said to be larger (mean length 4.73) and more tumid than $P$. lepidulus but, because of the variability of the Faure Island sample, these characters do not help determine our specimens as one species or the other. Since the Adams and Angas name is the older and has taxonomic priority, and Shark Bay is its type locality, that name is preferred for the Faure Island series as a provisional measure. Further study of this genus is needed to establish whether there are two or only a single species in the Shark Bay region.

\section{Geographic distribution}

Western Australia from the Abrolhos to Broome. If it is determined that $P$. lepidulus and $P$. beltiana are conspecific, then the range will be the arid and semi-arid lands of Central and Western Australia.

\section{Distribution and habitats on Faure Island}

Empty shells may be found among leaf litter under shrubs and spinifex throughout the island but no live or freshly dead specimens were found in spite of careful search. A subfossil sample (27 specimens) was picked from wind sorted debris in a red dune blowout on the western side of Faure Island $\left(25^{\circ} 51.321^{\prime} \mathrm{S} ; 113^{\circ} 51.772^{\prime} \mathrm{E}\right)$. It seems likely that this species aestivates during dry conditions and is active only episodically during infrequent rainy periods.

\section{SUCCINEIDAE}

Austrosuccinea cf. strigillata (Adams and Angas, 1864: 38; figured Cox, 1868, pl. 15, fig. 5). Type locality: Shark Bay.

\section{Geographic distribution \\ Unknown.}

\section{Distribution and habitats on Faure Island}

Like Themapupa, empty shells may be found among leaf litter under shrubs and spinifex throughout the island but no live or freshly dead specimens were found. A sample (nine specimens) was picked from wind sorted debris in a red dune blowout on the western side of Faure Island $\left(25^{\circ} 51.321^{\prime} S ; 113^{\circ} 51.772 ' E\right)$. The presence of this species in such an arid environment seems surprising although the fragile empty shells are quite common. They too may be active only during infrequent periods of rain.

\section{ACKNOWLEDGEMENTS}

The author thanks all the members of the field survey team for their assistance. George Kendrick and Shirley Slack-Smith of the Western Australian 
Museum gave helpful advice and comments on the taxonomy and distribution of the species discussed in this paper.

\section{REFERENCES}

Adams, A.A. and Angas, G.F. (1864). Descriptions of new species of shells, chiefly from Australia, in the collection of Mr Angas. Proceedings of the Zoological Society of London 1864: 35-40.

Alexander, W.B. (1916). The history of zoology in Western Australia. Part II. 1791-1829. Journal and Proceedings of the Royal Society of Western Australia 1: 83-149.

Benson, W.H. (1853). Characters of several Helices from West Australia and the Mauritius: with notes on some species Cyclostoma from Borneo. Annals and Magazine Natural History 11: 29-33.

Cox, J.C. (1864). Descriptions of twenty six new species of Australian land shells. Annals and Magazine Natural History 14: 180-185.

Cox, J.C. (1868). A Monograph of Australian Land Shells. Maddock, Sydney, NSW.

Iredale, T. (1939). A review of the land mollusca of Western Australia. Records of the Western Australian Museum and Art Gallery 2: 1-88, 5 pls.

Keighery, G. and Muir, W. (2008). Vegetation and vascular flora of Faure Island, Shark Bay, Western Australia. Records of the Western Australian Museum Supplement 75: 11-19.

Kendrick, G.W. (1978). New species of fossil nonmarine molluscs from Western Australia and evidence of late Quaternary climate change in the Shark Bay district. Royal Society of Western Australia 60: 49-60.
Kendrick, G.W and Wilson, B.R. (1975). Nomenclatural notes on the land snail genus Bothriembryon Pilsbry, 1894 (Pulmonata, Bulimidae), with redescriptions of the type and two other species. Records of the Western Australian Museum 3: 295-325, 4 pls.

Kendrick, G.W., Wyroll, K-H. and Szabo, B.J. (1991). Pliocene-Pleistocene coastal events and history along the western margin of Australia. Quaternary Science Reviews 10: 419-439.

'Lamarck, J.B. (1822). Histoire naturelle des animaux sans vertebres. 6(2). Paris.

Péron, M.F. (1807). Voyage de decouvertes aux terrès australes 1. L'Imprimerie Imperiale, Paris.

Pfieffer, L. (1864). Descriptions of seven new species of land shells from the collection of $\mathrm{H}$. Cuming Esq. Proceedings of the Zoological Society, London. 1863: 528.

Reeve, A. (1853). Conchologica Iconica. 7. Helix, pl. CLXXII, species 1162.

Solem, A. (1986). Pupilloid land snails from the south and mid-west coasts of Australia. Journal of the Malacological Society of Australia 7: 95-124.

Solem, A. (1997). Camaenid land snails from Western and central Australia (Mollusca: Pulmonata: Camaenidae. Records of the Western Australian Museum Supplement 50: 1461-1906.

Tate, T. (1894). Brief diagnosis of Mollusca from Central Australia. Transactions of the Royal Society of South Australia 18: 191-194.

Wilson, B. (2008). Background information on Faure Island, Shark Bay, Western Australia. Records of the Western Australian Museum Supplement 75: 1-9. 